\title{
DAYTIME AND NIGHTTIME SEAT BELT USE AT SELECTED SITES IN NEW MEXICO
}

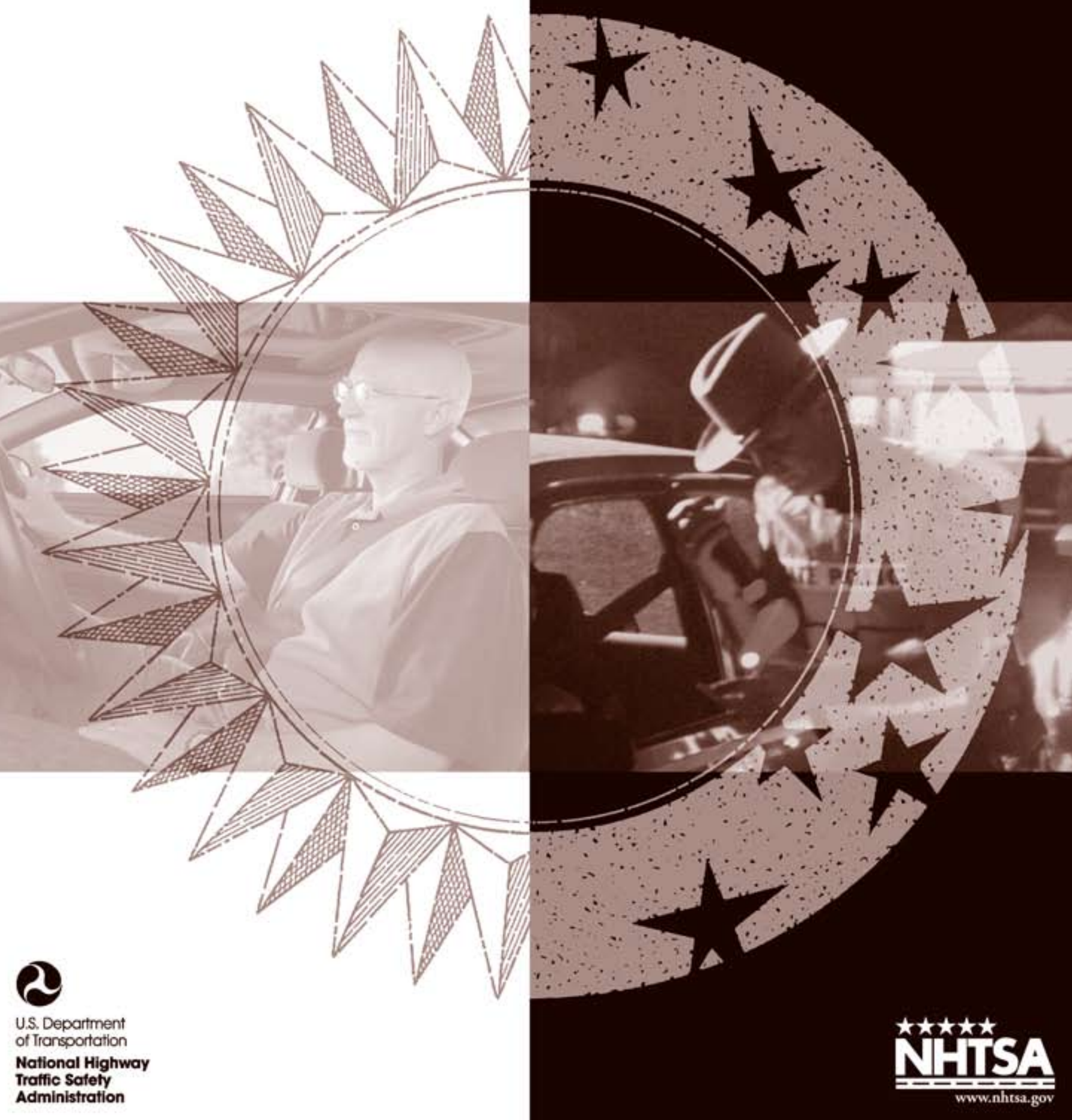


This publication is distributed by the U.S. Department of Transportation, National Highway Traffic Safety Administration, in the interest of information exchange. The opinions, findings, and conclusions expressed in this publication are those of the authors and not necessarily those of the Department of Transportation or the National Highway Traffic Safety Administration. The United States Government assumes no liability for its contents or use thereof. If trade or manufacturers' names or products are mentioned, it is because they are considered essential to the object of the publication and should not be construed as an endorsement. The United States Government does not endorse products or manufacturers. 


\begin{tabular}{|c|c|c|c|c|}
\hline $\begin{array}{l}\text { 1. Report No. } \\
\text { DOT HS } 810705\end{array}$ & \multicolumn{2}{|l|}{ 2. Government Accession No. } & \multicolumn{2}{|c|}{ 3. Recipient's Catalog No. } \\
\hline \multirow{2}{*}{\multicolumn{3}{|c|}{$\begin{array}{l}\text { 4. Title and Subtitle } \\
\text { Daytime and Nighttime Seat Belt Use at Selected Sites in New Mexico }\end{array}$}} & \multicolumn{2}{|c|}{$\begin{array}{l}\text { 5. Report Date } \\
\text { January } 2007\end{array}$} \\
\hline & & & \multicolumn{2}{|c|}{ 6. Performing Organization Code } \\
\hline \multicolumn{3}{|c|}{$\begin{array}{l}\text { 7. Author(s) } \\
\text { M. G. Solomon, N. K. Chaudhary, D. F. Preusser }\end{array}$} & \multicolumn{2}{|c|}{ 8. Performing Organization Report No. } \\
\hline \multicolumn{3}{|c|}{$\begin{array}{l}\text { 9. Performing Organization Name and Address } \\
\text { Preusser Research Group, Inc. } \\
7100 \text { Main Street } \\
\text { Trumbull, CT } 06611\end{array}$} & \multicolumn{2}{|c|}{$\begin{array}{l}\text { 11. Contract or Grant No. } \\
\text { NHTSA Contract DTNH22-98-D- } \\
45079\end{array}$} \\
\hline \multicolumn{3}{|c|}{$\begin{array}{l}\text { 12. Sponsoring Agency Name and Address } \\
\text { U.S. Department of Transportation } \\
\text { National Highway Traffic Safety Administration } \\
\text { 400 Seventh Street SW. } \\
\text { Washington, DC } 20590\end{array}$} & \multicolumn{2}{|c|}{$\begin{array}{l}\text { 13. Type of Report and Period Covered } \\
\text { Final Report }\end{array}$} \\
\hline \multicolumn{5}{|c|}{$\begin{array}{l}\text { 15. Supplementary Notes } \\
\text { The Contracting Officer's Technica }\end{array}$} \\
\hline \multicolumn{5}{|c|}{$\begin{array}{l}\text { Observational surveys of seat belt use were conducted at } 108 \text { observation sites across New Mexico during both } \\
\text { daytime and nighttime hours. Belt use at night measured } 6.2 \text { percentage points lower than daytime. Belt use was } \\
\text { related to sex, vehicle type, road type and population density. Increasing seat belt usage among occupants } \\
\text { traveling at night could substantially lessen injury and fatality rates among passenger vehicle occupants. }\end{array}$} \\
\hline \multicolumn{2}{|l|}{ 17. Key Words } & $\begin{array}{l}18 . \\
\text { Doc } \\
\text { Nati } \\
\text { Spri }\end{array}$ & $\begin{array}{l}\text { in Statement } \\
\text { is available th } \\
\text { echnical Infor } \\
\text { VA } 22161\end{array}$ & $\begin{array}{l}\text { ce } \\
\text { ot.gov }\end{array}$ \\
\hline $\begin{array}{l}\text { 19. Security Classif.(of this report) } \\
\text { Unclassified }\end{array}$ & $\begin{array}{r}\text { 20. Security Classif.(of this page) } \\
\text { Unclassified }\end{array}$ & & 21. No. of Pages & 22. Price \\
\hline
\end{tabular}




\section{Background}

Research has shown that the proper use of a shoulder/lap belt during a crash reduces the risk of death for front seat occupants by 45 percent and the risk of moderate-to-critical injury by 50 percent (Kahane, 2000). According to the National Highway Traffic Safety Administration's (NHTSA) Fatality Analysis Reporting System (FARS, 2003), belt use among fatally injured front seat occupants of passenger vehicles declines across the hours of night.

New York passed the Nation's first seat belt law in 1984. Belt use among front seat occupants of passenger vehicles increased from about 15 percent before the law to about 50 percent after the law. However, fatalities in New York decreased by only nine percent; far less than would be expected given the substantial rise in seat belt use. It was argued that high-crashrisk drivers were less likely to comply with the law than the general driving population. That is, those most in need of seat belts were least likely to buckle up. One such high-risk group are those who choose to drink and drive. Earlier data from checkpoints conducted in Ontario, Canada, showed that only 36 percent of drinking drivers wore their seat belts as compared with 62 percent of non-drinking drivers. Similar results were reported from British Columbia, Saskatchewan, and Denmark (Lawson et al., 1982; Noordzij et al., 1988).

Preusser et al. (1986) conducted a study to test the theory that very high-risk drivers (e.g., drinking drivers traveling at night) were the least likely to use seat belts. Preusser et al. tested this theory at and near bars and taverns in New York State six months after the New York seat belt law went into effect. Observations near taverns showed that 43 percent of drivers passing by during daylight hours were belted, 36 percent of drivers passing by the same locations at night (9 p.m.-2 a.m.) were belted, and just 24 percent of drivers leaving bar parking lots at night were belted. 
Results from the New York bar study clearly indicated that drinking drivers would be a very worthwhile target for a belt use enforcement campaign. Or, unbelted drivers at night would be a worthwhile target for an impaired-driving enforcement campaign. These two could be combined into one overall nighttime enforcement effort. The only known study to combine belt enforcement with alcohol enforcement was the Buckle Up and Drive Sober program in Binghamton, New York, a small upstate community with a self-contained media market (Wells et al., 1986). The program concept was that belt law violations would be enforced, particularly at night, and each driver stopped would be screened using a passive alcohol sensor. The effort included a series of combined belt-use and alcohol night checkpoints. The program, supported with paid media, ran from the fall of 1988 through the fall of 1990. Belt use was measured through day and night belt use observations. Drinking and driving was measured using voluntary and anonymous breath testing at checkpoints. During the course of the program, more than 5,000 drivers were tested for BAC at checkpoints, more than 10,000 drivers were observed for belt use during nighttime hours, and more than 10,000 drivers were observed at the same locations during daylight. Results indicated that the number of drinking drivers at checkpoints decreased from 23 percent before the program to 14 percent after. Belt use at night rose from 35 percent to 49 percent.

Chaudhary et al. (2005b) was the first statewide study to measure seat belt usage at night using a random stratified sampling plan compliant with Federal Register Guidelines for a daytime statewide survey of seat belt usage. This study included the collection of day and night belt use in Connecticut. Nighttime procedures were patterned after daytime observation procedures, insofar as possible. For the first time, a nighttime observational survey made use of night vision technology, enabling observers to make observations in not only well-lit locations, 
but also non-lit locations. The results of these surveys indicated higher statewide belt use during daytime hours (83 percent) compared to nighttime hours (77 percent).

Chaudhary et al. (2005a) was the first study to combine night vision technology with nighttime belt-use enforcement. The objective of this study was to evaluate the impact of a nighttime seat belt enforcement program. The program was conducted in Reading, Pennsylvania, a small city (population 81,201 ) with a self-contained media market. The program was conducted during September 2004 and only addressed nighttime seat belt use. Police patrols were equipped with near-military-grade night vision goggles. Press releases and news stories depicted the goggles as "new" technology available to police. The program was supported by earned media only. Bethlehem, Pennsylvania, served as a comparison community.

Observations of seat belt use were conducted both before and after the campaign in both Reading and in Bethlehem. Twenty observation sites were used in each city. All sites were within the borders of the cities proper. Local roads and interstates were excluded from observation. Local roads were excluded due to the low traffic volumes during night hours. Interstates were excluded because drivers on interstates are less likely to have been exposed to the local program. Observation sites were selected from three functional classes of roadway: principal arterial highways (5 sites), minor arterial roadways (11 sites), and urban collectors (4 sites). Reading sites were randomly chosen from existing traffic count locations. The traffic count locations are used by PennDOT to establish vehicle miles traveled (VMT) data. Sites in Bethlehem were randomly chosen from among all functional classes at a count station such that the number of each functional class of roadway was equal for both sites.

Day and night observations were conducted at the same observation sites. Daytime observations occurred from 9 a.m. until 3:59 p.m. Night observations took place from 9 p.m. 
until 3:59 a.m. Hours of the day (and night) did not differ by functional class. That is, there was no systematic difference in time of observation for the three functional classes. The same time of day for each site was used for the pre and post observations.

The Reading program was successful despite the short duration, lack of paid media, and the fact that Pennsylvania is a secondary belt use enforcement State. Night belt use increased by six percentage points; day belt use increased by three percentage points. A slight (not significant) decrease in belt use was seen in Bethlehem during the daytime; there was no change in nighttime belt use.

There have been few published studies in the United States devoted to nighttime seat belt use. All of these took place in the northeast. In addition, with exception of the 2004 Connecticut nighttime seat belt measurement, observations were always made in lighted locations. The present study, conducted in June 2005, took advantage of military-grade night vision technology to measure daytime versus nighttime belt use rates at the observation sites used for New Mexico's official Federal belt use measurement. The goal of these analyses is not to estimate seat belt use across the state of New Mexico but rather to examine the differences between daytime and nighttime seat belt use in several situations.

\section{Method}

The New Mexico Department of Health conducts an Annual Statewide Survey of Seat Belt Use, typically during the month of June. This survey is based on a random proportional selection of observational survey sites on roadways that represent the State's population demographics and roadway travel. Observations at the survey sites $(\mathrm{N}=108)$ are randomly distributed across all days of week and daylight hours of the day (7 a.m. -7 p.m.). 
This study used the same New Mexico Statewide Survey of Seat Belt Use observation sites, since it is representative of travel patterns across New Mexico roadways, at all hours and on all days of the week. Observations were made at each of these 108 sites once during the day and again at night.

Daytime observations followed New Mexico's survey procedures for their statewide survey. Observation start times for day observations were generally the same as in New Mexico's official survey. Observations were made for 20 minutes at each location. Paired observers collected data. Typically, one observer observed and one recorded data. Survey teams observed and recorded information regarding occupant type (driver or passenger), vehicle type (passenger car, pickup truck, SUV, or van), gender (male or female), and seat belt usage (wearing or not wearing). Day of week and hour of day were also recorded as was roadway type (Interstate, U.S./State highway, or local road). Roadways were sub-classified as located inside or outside city limits. Only front seat outboard passengers were observed.

Nighttime observations occurred between 9 p.m. and 3:59 a.m. at the same locations as daytime observations and usually on the night following the day observation. Nighttime observation periods lasted 45 , instead of 20 , minutes in order to sample a sufficient number of vehicles given the lower traffic volume at night. Observations at night were also made by pairs of observers. Observers recorded the same information during the day and at night. In locations with adequate overhead lighting, observations were made without vision-enhancing equipment. At many locations, adequate lighting did not exist in the vicinity of an observation site. In those situations, nighttime observations were aided by the use of night vision technology. This was typical in rural locations and locations outside of city limits. Autogated night vision goggles (XR-5 image enhancing tube) were used in tandem with an infrared spotlight (see Chaudhary et 
al., 2005b). This combination allowed for adequate illumination of the occupants of a vehicle even in the complete absence of lighting without affecting the occupants of the vehicle (as infrared light is not visible to the naked human eye but visible to the goggles). Once an observation was made, the results were verbalized to the other observer who recorded the data.

One modification made to New Mexico's statewide survey procedure was that the survey sites on Interstates were moved to the nearest on/off Interstate ramp. Both day and night observations were made at the new locations for comparability. This was done for the benefit of the nighttime survey where night-vision goggles were necessary. Night vision technology worked well in dim- and no-light environments, but using the technology to observe occupants at speeds in excess of $55 \mathrm{mph}$ was unworkable. Ramps provided an opportunity to observe Interstate travelers at slower speeds. Consequently, this decreased the number of observed occupants by excluding a greater number of occupants passing through on Interstates that otherwise could have been observed.

Exact positioning of observers was decided at each observation site just before daytime data collection was conducted. At that time, consideration was given to observer safety and ease of observation-data collection for both the day and nighttime observations. Whenever possible, observers attempted to conduct nighttime observations under lighted conditions, for safety and ease of operation.

This study was conducted during the first two weeks of June 2005, immediately following the May - June Click It or Ticket (CIOT) program, a widely publicized mobilization of law enforcement activities focused on seat belt nonusers. There were 9,707 observed occupants during the day and 5,791 observed occupants during the night. 
Analyses

Daytime surveys of statewide belt use are usually reported as weighted results. Weighting is based on 24-hour Average Daily Density Traffic (ADDT) counts, for which the large majority of traffic occurs during daytime hours. It is likely that the proportion of traffic on each functional class of roadway differs between day and night. This suggests that the 24-hour ADDT used for daytime weighting of seat belt use would be inappropriate for nighttime data (See Chaudhary et al., 2005b). Ideally, a separate set of weights based on traffic counts occurring only during nighttime hours would be used for the night observation data. These counts, however, were unavailable, rendering weights for nighttime data impossible. Therefore, because of possible sampling bias caused by unweighted nighttime belt counts, this study was unable to generalize daytime and nighttime differences in belt use to the entire State. Instead, this study provides an exploratory and descriptive account of the daytime and nighttime belt use at a representative sample of sites in New Mexico.

\section{Albuquerque}

Greater Albuquerque, with approximately 43 percent of New Mexico's population, differs from the remainder of the State in terms of population density. Also, observations in Albuquerque were done immediately after CIOT while observations in the remainder of the State were done in succeeding weeks.

Survey Validity

The daytime observed belt use rate across all individual observations in this study $(87.6 \%)$ was comparable to the official daytime statewide belt use survey $(89.5 \%)$. The data collection timing between the current observation and the official statewide survey were slightly temporally displaced. Specifically, the New Mexico Annual Statewide Survey of Seat Belt Use 
had a higher percentage of observations occurring within the first week following CIOT. This time period immediately after CIOT likely had a higher belt use rate than any later time period. To compensate for the differences in timing, we compared raw data from the current survey with the official statewide survey for the subset of sites whose observations all occurred within the first week after CIOT. For the subsets, both surveys produced belt use rates of 88 percent. Therefore, the daytime observations conducted as part of this study were directly comparable to the daytime observations conducted by the State of New Mexico.

\section{Results}

\section{Daytime and Nighttime Belt Use}

Belt use observations across all sites were combined for these analyses. There were 9,707 observations during the day and 5,791 observations at night. Overall, the average seat belt use rate across sites was 86.6 percent during the day and 80.4 percent at night. (For a summary and results from each site, see Appendix A.)

\section{Occupant Characteristics}

The daytime drivers' belt use of 86.9 percent appeared greater than the nighttime drivers' belt use of 80.7 percent. This belt use pattern was similar for passengers who had a daytime belt use rate of 86 percent and a nighttime belt use rate of 81.1 percent

Both men and women had higher belt use rates during the day than they did at night (see Appendix A. Table 1.). Specifically, men wore their seat belts 85.1 percent of the time during the day and 78.2 percent of the time at night. Women wore their belts 89.9 percent of the time during the day and 86.3 percent of the time at night.

Vehicle Characteristics 
Occupant belt usage varied by vehicle type. Belt usage measured higher in passenger cars (Day: 90.4\%; Night: 80.9\%), SUVs (Day: 87.9\%; Night: 85.3\%), and vans (Day: 88.2\%; Night: 87.9\%); compared to pickup trucks (Day: 83.8\%; Night: 77.7\%). This was true both during the day and at night.

\section{Roadway Characteristics}

Belt use was higher during the day for observation sites both outside city limits (Day: 84.7\%; Night: 77.6\%) and inside city limits (Day: 88.6\%; Night: 83.1\%).

Belt usage measured lower at night compared to day regardless of road type (see Table 1). Belt use on Interstates was 88.1 percent during the day and 83.2 percent at night. Belt use on non-Interstates was 86.2 percent during the day and 79.6 percent at night.

\section{Discussion}

The results of the observational surveys presented here suggest that belt usage is lower at night than during the day. These results are similar to those reported by Chaudhary et al. (2005b). Day/night belt use differences were consistent for men and women, for drivers and

passengers, across road types, and for urban (inside city limits) and rural locations. The results of this study also suggest that the day/night belt use difference exists across vehicle types.

Chaudhary et al. (2005b) found urban versus rural differences in the day/night gap for seat belt use in Connecticut. This effect was not seen in New Mexico, but it should be noted that what is considered "rural" versus "urban" for the State of Connecticut may be very different than the New Mexico areas inside city limits and those outside city limits.

The statewide nighttime belt use survey in the State of Connecticut indicated that the gap between day and night belt use may be reduced immediately following CIOT (Chaudhary et al., 2005b). It is important to note that the current study included a single wave of observations 
conducted immediately after the end of New Mexico's CIOT program. Thus, it is possible that there is a bigger difference between daytime and nighttime belt use during other times of the year.

The seat belt use figures reported here cannot necessarily be considered descriptive of the entire State of New Mexico in the same way that the reported statewide belt use figure is representative. There is no weighting of the site-by-site results, which would be necessary to make them representative of the whole State. This is not to say that these results would not be expected to be the same for the State as a whole. Indeed, the similarity of these results to Connecticut's results and the fact that the observation sites were chosen statewide to be representative (albeit when weighted appropriately) suggest that the results are likely indicative of a Statewide day/night difference in seat belt use.

There may be some combination of at least two factors behind the lower belt use at night. First, people who wear seat belts during the day may be less likely to buckle up at night. Next, drivers (and passengers) who are less likely to buckle up in general may be more likely to be on the road at night. This study lends support to the first premise, since comparable groups (defined by men-women, vehicle type, roadway type, and urban-rural) showed comparably lower nighttime belt use rates. However, this study can't rule out the possible effects of other factors, such as age, race, education, and income, in producing the observed daytime/nighttime belt use difference. Because these additional factors were not measured, it isn't possible to definitively determine whether the observed differences were due to a reduced tendency to buckle up of the same people at night, or to less-likely-to-buckle people on the roads at night, or to some combination. 
Regardless, nationwide traffic fatality rates are highest at night; the hours of 10 p.m. until 3:59 a.m. account for 25 percent of traffic fatalities (FARS 1998 - 2003), with only a relatively small percentage of traffic volume (about 12-15\%, according to Hallenbeck et al., 1997). These results suggest that this effect can be due in part to the lower belt use across all subcategories of occupants at night.

Grant-funded enforcement programs to increase seat belt usage are conducted almost exclusively during daytime hours. Selective Traffic Enforcement Programs like Click It or Ticket can rapidly improve belt usage. Fully implemented CIOT programs result in immediate, short-term improvements in belt usage, and nearly all States in the Nation use CIOT as a means of improving their statewide belt use rates. CIOT programs should use data such as that presented here to help plan and direct efforts toward times and locations most in need of improvement. Tracking belt usage at all hours of the day and night and focusing programs where they are needed most should lead to further decreases in injuries and fatalities. 


\section{References}

Chaudhary, N.K., Alonge, M.A. and Preusser, D.F., (2005a). Evaluation of the Reading PA nighttime safety belt enforcement campaign: September 2004. Journal of Safety Research, 26:321-326

Chaudhary, N.K., Geary, L.L., Preusser, D.F. and Cosgrove, L.A., (December, 2005b). Connecticut's Day and Night Safety Belt Use, DOT HS 809 954, National Highway Traffic Safety Administration, Washington, DC.

Hallenbeck, M. E., Smith, B., Cornell-Martinez, Wilkinson, J., (1997). Vehicle Volume Distributions by Classification, FHWA-PL-97-025.

Kahane, C.J., (December, 2000). Fatality reduction by safety belts for front-seat occupants of cars and light trucks: Updated and expanded estimates based on 1986-99 FARS data, DOT HS 809 199, National Highway Traffic Safety Administration, Washington, DC.

Lawson, J., Arora, H., Jonah, B., Krzyzewski, J., Smith, G., and Stewart, D., (1982). In: $26^{\text {th }}$ Annual Proceedings, American Association of Automotive Medicine, 26:375-388.

Noordzij, P., Meester, A., and Verschuur, W. (1988). Night-time driving: The use of seat-belts and alcohol. Ergonomics, 31:663-668.

Preusser D.F., Williams A.F., and Lund A.K., (1986). Seat belt use among New York bar patrons Journal of public health policy, 7: 470-9.

Romero, I and Chatterjee, B (2004). New Mexico Safety Belt Survey 2004 Report. Prepared for: New Mexico State Highway and Transportation Department Traffic Safety Bureau Project No. 04-OP-IG-P02

Wells, J.K., Preusser, D.F. and Williams, A.F. Enforcing Alcohol-Impaired Driving and Seat Belt Use Laws, Binghamton, New York. Journal of Safety Research, 1992, 23, 63-71. 
Winer, B.J. (1971). Statistical Principles in Experimental Design ( $2^{\text {nd }}$ Ed.). McGraw-Hill: New York. 
Table 1. Average Rate of Belt Usage, Day and Night

\begin{tabular}{|c|c|c|c|}
\hline & $\begin{array}{c}\text { Day (\%) } \\
\left(\mathrm{N}^{+}\right)\end{array}$ & $\begin{array}{c}\text { Night (\%) } \\
\left(\mathrm{N}^{+}\right)\end{array}$ & $\begin{array}{l}\text { Day/Night } \\
\text { Difference }\end{array}$ \\
\hline \multicolumn{4}{|l|}{ OCCUPANT } \\
\hline Drivers & $\begin{array}{c}86.9 \\
(7,340)\end{array}$ & $\begin{array}{c}80.7 \\
(4,244)\end{array}$ & 6.2 \\
\hline Passengers & $\begin{array}{c}86.0 \\
(2,367)\end{array}$ & $\begin{array}{c}81.1 \\
(1,547)\end{array}$ & 4.9 \\
\hline \multicolumn{4}{|l|}{ SEX } \\
\hline Men & $\begin{array}{c}85.1 \\
(5,368)\end{array}$ & $\begin{array}{c}78.2 \\
(3,420)\end{array}$ & 6.9 \\
\hline Women & $\begin{array}{c}89.9 \\
(4,260)\end{array}$ & $\begin{array}{c}86.3 \\
(2,309)\end{array}$ & 3.6 \\
\hline \multicolumn{4}{|l|}{ VEHICLE TYPE } \\
\hline Cars & $\begin{array}{c}90.4 \\
(4,165)\end{array}$ & $\begin{array}{c}80.9 \\
(3,257)\end{array}$ & 9.5 \\
\hline Pickups & $\begin{array}{c}83.8 \\
(2,926)\end{array}$ & $\begin{array}{c}77.7 \\
(1,275)\end{array}$ & 6.1 \\
\hline SUVs & $\begin{array}{c}87.9 \\
(1,770)\end{array}$ & $\begin{array}{l}85.3 \\
(881)\end{array}$ & 2.6 \\
\hline Vans & $\begin{array}{l}88.2 \\
(842)\end{array}$ & $\begin{array}{l}87.9 \\
(375)\end{array}$ & 0.3 \\
\hline \multicolumn{4}{|l|}{ CITY LIMITS } \\
\hline Inside & $\begin{array}{c}88.6 \\
(5,705)\end{array}$ & $\begin{array}{c}83.1 \\
(3,199)\end{array}$ & 5.5 \\
\hline Outside & $\begin{array}{c}84.7 \\
(4,002)\end{array}$ & $\begin{array}{c}77.6 \\
(2,592)\end{array}$ & 7.1 \\
\hline \multicolumn{4}{|l|}{ ROAD TYPE } \\
\hline Interstates & $\begin{array}{c}88.1 \\
(1,357)\end{array}$ & $\begin{array}{l}83.2 \\
(944)\end{array}$ & 4.9 \\
\hline Non-Interstates & $\begin{array}{c}86.2 \\
(8,350) \\
\end{array}$ & $\begin{array}{c}79.6 \\
(4,847) \\
\end{array}$ & 6.6 \\
\hline
\end{tabular}

$\overline{\dagger \dagger \text { For some observations, Sex and/or vehicle type were not determined. }}$ 
Table 2. Day and Night Driver Belt Use in New Mexico, by Site

\begin{tabular}{|c|c|c|c|c|c|c|c|c|}
\hline \multirow[b]{2}{*}{ Location } & \multirow[b]{2}{*}{ Road Type* } & \multirow[b]{2}{*}{ City Limits** } & \multicolumn{3}{|c|}{ Driver Day } & \multicolumn{3}{|c|}{ Driver Night } \\
\hline & & & Yes & No & Rate & Yes & No & Rate \\
\hline Albuquerque & I & $\mathrm{N}$ & 39 & 1 & $97.5 \%$ & 58 & 0 & $100 \%$ \\
\hline Santa Fe to the South & I & $\mathrm{N}$ & 76 & 15 & $83.5 \%$ & 100 & 16 & $86.2 \%$ \\
\hline Santa Fe to the South & I & $\mathrm{N}$ & 82 & 11 & $88.2 \%$ & 73 & 2 & $97.3 \%$ \\
\hline Santa Fe to the South & I & $\mathrm{N}$ & 8 & 0 & $100 \%$ & 8 & 1 & $88.9 \%$ \\
\hline Las Cruces & I & $\mathrm{N}$ & 27 & 1 & $96.4 \%$ & 5 & 1 & $83.3 \%$ \\
\hline Las Cruces - El Paso & I & $\mathrm{N}$ & 34 & 4 & $89.5 \%$ & 38 & 6 & $86.4 \%$ \\
\hline Las Cruces - El Paso & 1 & $\mathrm{~N}$ & 63 & 2 & $96.9 \%$ & 11 & 0 & $100 \%$ \\
\hline Demming & I & $\mathrm{N}$ & 0 & 1 & $0.0 \%$ & 1 & 0 & $100 \%$ \\
\hline Demming & I & $\mathrm{N}$ & 7 & 1 & $87.5 \%$ & 1 & 1 & $50.0 \%$ \\
\hline Espinoza & 1 & U & 61 & 10 & $85.9 \%$ & 51 & 22 & $69.9 \%$ \\
\hline Gallup & 1 & U & 41 & 3 & $93.2 \%$ & 4 & 0 & $100 \%$ \\
\hline Gallup & 1 & $U$ & 56 & 7 & $88.9 \%$ & 69 & 19 & $78.4 \%$ \\
\hline Gallup & I & $\mathrm{N}$ & 9 & 0 & $100 \%$ & 13 & 2 & $86.7 \%$ \\
\hline Gallup to the East & I & $\mathrm{N}$ & 17 & 0 & $100 \%$ & 0 & 2 & $0.0 \%$ \\
\hline Las Cruces & I & $U$ & 12 & 0 & $10 \%$ & 4 & 0 & $100 \%$ \\
\hline Las Cruces & I & $U$ & 55 & 1 & $98.2 \%$ & 79 & 6 & $92.9 \%$ \\
\hline Las Cruces & I & $U$ & 101 & 1 & $99.0 \%$ & 37 & 7 & $84.1 \%$ \\
\hline Las Cruces & I & $U$ & 33 & 5 & $86.8 \%$ & 24 & 3 & $88.9 \%$ \\
\hline Albuquerque & I & U & 21 & 4 & $84.0 \%$ & 9 & 2 & $81.8 \%$ \\
\hline Albuquerque & I & U & 63 & 3 & $95.5 \%$ & 6 & 0 & $100 \%$ \\
\hline Albuquerque & I & $U$ & 25 & 2 & $92.6 \%$ & 4 & 0 & $100 \%$ \\
\hline Albuquerque & I & $U$ & 55 & 7 & $88.7 \%$ & 6 & 1 & $85.7 \%$ \\
\hline Albuquerque & I & $U$ & 66 & 5 & $93.0 \%$ & 8 & 2 & $80.0 \%$ \\
\hline Albuquerque & NM & $\mathrm{N}$ & 78 & 4 & $95.1 \%$ & 81 & 14 & $85.3 \%$ \\
\hline Albuquerque & NM & $\mathrm{N}$ & 28 & 2 & $93.3 \%$ & 2 & 3 & $40.0 \%$ \\
\hline Albuquerque & NM & $\mathrm{N}$ & 48 & 6 & $88.9 \%$ & 64 & 9 & $87.7 \%$ \\
\hline Santa Fe to the East & NM & $\mathrm{N}$ & 35 & 8 & $81.4 \%$ & 14 & 5 & $73.7 \%$ \\
\hline Carlsbad & NM & N & 64 & 7 & $90.1 \%$ & 126 & 22 & $85.1 \%$ \\
\hline Clovis & NM & $\mathrm{N}$ & 29 & 9 & $76.3 \%$ & 6 & 0 & $100 \%$ \\
\hline Las Cruces - El Paso & NM & $\mathrm{N}$ & 54 & 1 & $98.2 \%$ & 150 & 5 & $96.8 \%$ \\
\hline El Rancho - Santa Fe & NM & $\mathrm{N}$ & 41 & 5 & $89.1 \%$ & 14 & 2 & $87.5 \%$ \\
\hline Espanola -Santa Fe & NM & $U$ & 62 & 22 & $73.8 \%$ & 9 & 10 & $47.4 \%$ \\
\hline Farmington & NM & $\mathrm{N}$ & 33 & 3 & $91.7 \%$ & 16 & 2 & $88.9 \%$ \\
\hline Farmington & NM & $\mathrm{N}$ & 26 & 4 & $86.7 \%$ & 23 & 6 & $79.3 \%$ \\
\hline Gallup & NM & $\mathrm{N}$ & 57 & 11 & $83.8 \%$ & 15 & 0 & $100 \%$ \\
\hline Hobbs & NM & $U$ & 97 & 26 & $78.9 \%$ & 91 & 36 & $71.7 \%$ \\
\hline Hobbs & NM & $\mathrm{N}$ & 60 & 8 & $88.2 \%$ & 24 & 8 & $75.0 \%$ \\
\hline Lovington & NM & $\mathrm{N}$ & 27 & 14 & $65.9 \%$ & 17 & 9 & $65.4 \%$ \\
\hline Lovington & NM & $\mathrm{N}$ & 66 & 25 & $72.5 \%$ & 18 & 9 & $66.7 \%$ \\
\hline Tijeras & NM & $\mathrm{N}$ & 45 & 6 & $88.2 \%$ & 13 & 3 & $81.3 \%$ \\
\hline Las Cruces & NM & U & 25 & 4 & $86.2 \%$ & 4 & 0 & $100 \%$ \\
\hline
\end{tabular}




\begin{tabular}{|c|c|c|c|c|c|c|c|c|}
\hline \multirow[t]{2}{*}{ Table 2. cont } & \multirow[b]{2}{*}{ Road Type* } & \multirow[b]{2}{*}{ City Limits** } & \multicolumn{3}{|c|}{ Driver Day } & \multicolumn{3}{|c|}{ Driver Night } \\
\hline & & & Yes & No & Rate & Yes & No & Rate \\
\hline Albuquerque & NM & $U$ & 29 & 2 & $93.5 \%$ & 7 & 3 & $70.0 \%$ \\
\hline Albuquerque & NM & $U$ & 71 & 12 & $85.5 \%$ & 45 & 7 & $86.5 \%$ \\
\hline Albuquerque & NM & $U$ & 93 & 13 & $87.7 \%$ & 68 & 24 & $73.9 \%$ \\
\hline Albuquerque & NM & $U$ & 121 & 4 & $96.8 \%$ & 54 & 8 & $87.1 \%$ \\
\hline Albuquerque & NM & $U$ & 117 & 17 & $87.3 \%$ & 113 & 23 & $83.1 \%$ \\
\hline Alamagordo & US & $\mathrm{N}$ & 69 & 10 & $87.3 \%$ & 40 & 10 & $80.0 \%$ \\
\hline Alamagordo - White Sands & US & $\mathrm{N}$ & 66 & 9 & $88.0 \%$ & 53 & 11 & $82.8 \%$ \\
\hline Alamogordo & US & $U$ & 42 & 13 & $76.4 \%$ & 11 & 1 & $91.7 \%$ \\
\hline Santa Fe to the North & US & $\mathrm{N}$ & 26 & 4 & $86.7 \%$ & 6 & 1 & $85.7 \%$ \\
\hline Santa Fe to the North & US & $\mathrm{N}$ & 18 & 1 & $94.7 \%$ & 5 & 0 & $100 \%$ \\
\hline Carlsbad & US & $U$ & 137 & 30 & $82.0 \%$ & 14 & 7 & $66.7 \%$ \\
\hline Carlsbad & US & $U$ & 84 & 19 & $81.6 \%$ & 23 & 4 & $85.2 \%$ \\
\hline Carlsbad & US & $U$ & 89 & 16 & $84.8 \%$ & 13 & 9 & $59.1 \%$ \\
\hline Clovis & US & $U$ & 86 & 14 & $86.0 \%$ & 38 & 7 & $84.4 \%$ \\
\hline Clovis & US & $\mathrm{N}$ & 89 & 12 & $88.1 \%$ & 88 & 20 & $81.5 \%$ \\
\hline Clovis & US & $\mathrm{N}$ & 81 & 8 & $91.0 \%$ & 22 & 3 & $88.0 \%$ \\
\hline Clovis & US & $\mathrm{N}$ & 33 & 6 & $84.6 \%$ & 18 & 3 & $85.7 \%$ \\
\hline Las Cruces & US & $\mathrm{N}$ & 99 & 8 & $92.5 \%$ & 48 & 4 & $92.3 \%$ \\
\hline Las Cruces & US & $\mathrm{N}$ & 121 & 10 & $92.4 \%$ & 23 & 3 & $88.5 \%$ \\
\hline Las Cruces - El Paso & US & $\mathrm{N}$ & 38 & 5 & $88.4 \%$ & 33 & 4 & $89.2 \%$ \\
\hline Espinoza & US & N & 74 & 28 & $72.5 \%$ & 101 & 26 & $79.5 \%$ \\
\hline Farmington - Bloomfield & US & $\mathrm{N}$ & 28 & 9 & $75.7 \%$ & 0 & 0 & $\mathrm{n} / \mathrm{a}$ \\
\hline Farmington - Shiprock & US & N & 27 & 15 & $64.3 \%$ & 61 & 34 & $64.2 \%$ \\
\hline Hobbs & US & U & 68 & 26 & $72.3 \%$ & 42 & 9 & $82.4 \%$ \\
\hline Hobbs & US & $\mathrm{N}$ & 53 & 11 & $82.8 \%$ & 10 & 11 & $47.6 \%$ \\
\hline Lovington & US & $\mathrm{N}$ & 15 & 8 & $65.2 \%$ & 2 & 8 & $20.0 \%$ \\
\hline Roswell & US & $U$ & 121 & 19 & $86.4 \%$ & 20 & 9 & $69.0 \%$ \\
\hline Roswell & US & $\mathrm{N}$ & 37 & 4 & $90.2 \%$ & 0 & 2 & $0.0 \%$ \\
\hline Roswell & US & $\mathrm{N}$ & 37 & 2 & $94.9 \%$ & 1 & 2 & $33.3 \%$ \\
\hline Roswell & US & N & 67 & 13 & $83.8 \%$ & 3 & 4 & $42.9 \%$ \\
\hline Roswell to the East & US & $\mathrm{N}$ & 9 & 2 & $81.8 \%$ & 7 & 0 & $100 \%$ \\
\hline Roswell to the South & US & N & 34 & 7 & $82.9 \%$ & 8 & 1 & $88.9 \%$ \\
\hline Taos to the West & US & $\mathrm{N}$ & 44 & 11 & $80.0 \%$ & 5 & 0 & $100 \%$ \\
\hline Albuquerque & z & $\mathrm{N}$ & 51 & 8 & $86.4 \%$ & 38 & 7 & $84.4 \%$ \\
\hline Albuquerque & z & $\mathrm{N}$ & 117 & 12 & $90.7 \%$ & 63 & 8 & $88.7 \%$ \\
\hline Santa Fe & $z$ & $U$ & 81 & 13 & $86.2 \%$ & 6 & 1 & $85.7 \%$ \\
\hline Santa Fe & z & $U$ & 100 & 19 & $84.0 \%$ & 9 & 0 & $100 \%$ \\
\hline Santa Fe & $z$ & U & 20 & 3 & $87.0 \%$ & 21 & 1 & $95.5 \%$ \\
\hline Santa Fe & z & $U$ & 56 & 8 & $87.5 \%$ & 81 & 9 & $90.0 \%$ \\
\hline Carlsbad & $z$ & U & 57 & 9 & $86.4 \%$ & 53 & 21 & $71.6 \%$ \\
\hline Clovis to the North & $z$ & N & 22 & 4 & $84.6 \%$ & 0 & 0 & $\mathrm{n} / \mathrm{a}$ \\
\hline Las Cruces & z & $\mathrm{N}$ & 115 & 15 & $88.5 \%$ & 12 & 0 & $100 \%$ \\
\hline
\end{tabular}




\begin{tabular}{|c|c|c|c|c|c|c|c|c|}
\hline \multicolumn{3}{|l|}{ Table 2. cont } & \multicolumn{3}{|c|}{ Driver Day } & \multicolumn{3}{|c|}{ Driver Night } \\
\hline Location & Road Type* & City Limits $^{* *}$ & Yes & No & Rate & Yes & No & Rate \\
\hline Las Cruces - El Paso & z & $\mathrm{N}$ & 138 & 1 & $99.3 \%$ & 7 & 0 & $100 \%$ \\
\hline Eunice & z & $\mathrm{N}$ & 24 & 6 & $80.0 \%$ & 22 & 14 & $61.1 \%$ \\
\hline Farmington & z & $U$ & 67 & 6 & $91.8 \%$ & 26 & 6 & $81.3 \%$ \\
\hline Farmington & z & $U$ & 44 & 15 & $74.6 \%$ & 5 & 3 & $62.5 \%$ \\
\hline Gallup & $\mathrm{z}$ & $U$ & 81 & 18 & $81.8 \%$ & 0 & 0 & $\mathrm{n} / \mathrm{a}$ \\
\hline Hobbs & z & $U$ & 102 & 24 & $81.0 \%$ & 40 & 16 & $71.4 \%$ \\
\hline Lovington & $z$ & $\mathrm{~N}$ & 20 & 9 & $69.0 \%$ & 32 & 13 & $71.1 \%$ \\
\hline Las Cruces & $z$ & U & 66 & 7 & $90.4 \%$ & 24 & 8 & $75.0 \%$ \\
\hline Las Cruces & $z$ & U & 83 & 13 & $86.5 \%$ & 22 & 5 & $81.5 \%$ \\
\hline Las Cruces & $z$ & $U$ & 86 & 8 & $91.5 \%$ & 87 & 15 & $85.3 \%$ \\
\hline Las Cruces & $z$ & $U$ & 49 & 2 & $96.1 \%$ & 10 & 3 & $76.9 \%$ \\
\hline Las Cruces & $z$ & $U$ & 67 & 7 & $90.5 \%$ & 26 & 5 & $83.9 \%$ \\
\hline Las Cruces & z & $U$ & 78 & 5 & $94.0 \%$ & 32 & 2 & $94.1 \%$ \\
\hline Las Cruces & z & U & 133 & 12 & $91.7 \%$ & 23 & 2 & $92.0 \%$ \\
\hline Las Cruces & $z$ & $U$ & 119 & 4 & $96.7 \%$ & 93 & 7 & $93.0 \%$ \\
\hline Albuquerque & z & $U$ & 51 & 1 & $98.1 \%$ & 59 & 5 & $92.2 \%$ \\
\hline Albuquerque & $z$ & U & 102 & 9 & $91.9 \%$ & 120 & 18 & $87.0 \%$ \\
\hline Albuquerque & z & $U$ & 45 & 4 & $91.8 \%$ & 4 & 2 & $66.7 \%$ \\
\hline Albuquerque & z & U & 63 & 6 & $91.3 \%$ & 101 & 12 & $89.4 \%$ \\
\hline Albuquerque & z & $U$ & 69 & 4 & $94.5 \%$ & 18 & 1 & $94.7 \%$ \\
\hline Albuquerque & $z$ & $U$ & 143 & 11 & $92.9 \%$ & 78 & 10 & $88.6 \%$ \\
\hline Albuquerque & $z$ & $U$ & 67 & 6 & $91.8 \%$ & 14 & 3 & $82.4 \%$ \\
\hline Albuquerque & z & $U$ & 82 & 6 & $93.2 \%$ & 72 & 4 & $94.7 \%$ \\
\hline Albuquerque & z & $U$ & 35 & 3 & $92.1 \%$ & 33 & 7 & $82.5 \%$ \\
\hline Albuquerque & z & U & 55 & 8 & $87.3 \%$ & 28 & 5 & $84.8 \%$ \\
\hline
\end{tabular}

${ }^{*} \mathrm{I}=$ Interstate, $\mathrm{NM}=$ State, US = US route, $\mathrm{z}=$ Local

${ }^{* *} \mathrm{~N}=$ Outside City Limits, $\mathrm{U}=$ Urban 
Table 3. Day and Night Passenger Belt Use in New Mexico, by Site

\begin{tabular}{|c|c|c|c|c|c|c|c|c|}
\hline \multirow[b]{2}{*}{ Location } & \multirow[b]{2}{*}{ Road Type* } & \multirow[b]{2}{*}{ City Limits** } & \multicolumn{3}{|c|}{ Passenger Day } & \multicolumn{3}{|c|}{ Passenger Night } \\
\hline & & & Yes & No & Rate & Yes & No & Rate \\
\hline Albuquerque & I & $\mathrm{N}$ & 17 & 0 & $100 \%$ & 18 & 1 & $94.7 \%$ \\
\hline Santa Fe to the South & I & $\mathrm{N}$ & 19 & 5 & $79.2 \%$ & 34 & 5 & $87.2 \%$ \\
\hline Santa Fe to the South & I & $\mathrm{N}$ & 32 & 7 & $82.1 \%$ & 12 & 0 & $100 \%$ \\
\hline Santa Fe to the South & I & $\mathrm{N}$ & 1 & 0 & $100 \%$ & 3 & 0 & $100 \%$ \\
\hline Las Cruces & । & $\mathrm{N}$ & 5 & 1 & $83.3 \%$ & 2 & 1 & $66.7 \%$ \\
\hline Las Cruces - El Paso & I & $\mathrm{N}$ & 10 & 1 & $90.9 \%$ & 15 & 0 & $100 \%$ \\
\hline Las Cruces - El Paso & I & $\mathrm{N}$ & 19 & 1 & $95.0 \%$ & 3 & 0 & $100 \%$ \\
\hline Demming & I & $\mathrm{N}$ & 0 & 0 & n/a & 0 & 0 & $\mathrm{n} / \mathrm{a}$ \\
\hline Demming & I & $\mathrm{N}$ & 4 & 1 & $80.0 \%$ & 0 & 0 & $\mathrm{n} / \mathrm{a}$ \\
\hline Espinoza & I & U & 19 & 1 & $95.0 \%$ & 15 & 10 & $60.0 \%$ \\
\hline Gallup & I & $U$ & 27 & 4 & $87.1 \%$ & 0 & 1 & $0.0 \%$ \\
\hline Gallup & I & $U$ & 19 & 1 & $95.0 \%$ & 32 & 16 & $66.7 \%$ \\
\hline Gallup & I & N & 7 & 0 & $100 \%$ & 5 & 1 & $83.3 \%$ \\
\hline Gallup to the East & I & $\mathrm{N}$ & 7 & 0 & $100 \%$ & 0 & 0 & $\mathrm{n} / \mathrm{a}$ \\
\hline Las Cruces & I & U & 9 & 0 & $100 \%$ & 1 & 0 & $100 \%$ \\
\hline Las Cruces & I & U & 12 & 1 & $92.3 \%$ & 29 & 3 & $90.6 \%$ \\
\hline Las Cruces & I & U & 22 & 1 & $95.7 \%$ & 11 & 1 & $91.7 \%$ \\
\hline Las Cruces & I & U & 15 & 2 & $88.2 \%$ & 9 & 0 & $100 \%$ \\
\hline Albuquerque & I & U & 12 & 5 & $70.6 \%$ & 2 & 0 & $100 \%$ \\
\hline Albuquerque & 1 & U & 20 & 2 & $90.9 \%$ & 3 & 0 & $100 \%$ \\
\hline Albuquerque & I & $U$ & 3 & 1 & $75.0 \%$ & 1 & 0 & $100 \%$ \\
\hline Albuquerque & 1 & U & 1 & 1 & $50.0 \%$ & 6 & 0 & $100 \%$ \\
\hline Albuquerque & I & U & 6 & 1 & $85.7 \%$ & 0 & 2 & $0.0 \%$ \\
\hline Albuquerque & NM & $\mathrm{N}$ & 22 & 0 & $100 \%$ & 39 & 3 & $92.9 \%$ \\
\hline Albuquerque & NM & $\mathrm{N}$ & 7 & 0 & $100 \%$ & 2 & 0 & $100 \%$ \\
\hline Albuquerque & NM & $\mathrm{N}$ & 20 & 7 & $74.1 \%$ & 19 & 4 & $82.6 \%$ \\
\hline Santa Fe to the East & NM & $\mathrm{N}$ & 8 & 1 & $88.9 \%$ & 4 & 0 & $100 \%$ \\
\hline Carlsbad & NM & $\mathrm{N}$ & 23 & 0 & $100 \%$ & 37 & 7 & $84.1 \%$ \\
\hline Clovis & NM & N & 7 & 1 & $87.5 \%$ & 0 & 0 & $\mathrm{n} / \mathrm{a}$ \\
\hline Las Cruces - El Paso & NM & $\mathrm{N}$ & 23 & 0 & $100 \%$ & 66 & 1 & $98.5 \%$ \\
\hline El Rancho - Santa Fe & NM & $\mathrm{N}$ & 17 & 2 & $89.5 \%$ & 4 & 0 & $100 \%$ \\
\hline Espanola -Santa Fe & NM & U & 29 & 13 & $69.0 \%$ & 2 & 7 & $22.2 \%$ \\
\hline Farmington & NM & $\mathrm{N}$ & 10 & 1 & $90.9 \%$ & 9 & 1 & $90.0 \%$ \\
\hline Farmington & NM & N & 6 & 4 & $60.0 \%$ & 8 & 3 & $72.7 \%$ \\
\hline Gallup & NM & $\mathrm{N}$ & 9 & 4 & $69.2 \%$ & 3 & 0 & $100 \%$ \\
\hline Hobbs & NM & U & 29 & 11 & $72.5 \%$ & 47 & 9 & $83.9 \%$ \\
\hline Hobbs & NM & $\mathrm{N}$ & 27 & 7 & $79.4 \%$ & 12 & 9 & $57.1 \%$ \\
\hline Lovington & NM & $\mathrm{N}$ & 9 & 6 & $60.0 \%$ & 2 & 4 & $33.3 \%$ \\
\hline Lovington & NM & $\mathrm{N}$ & 21 & 3 & $87.5 \%$ & 8 & 3 & $72.7 \%$ \\
\hline Tijeras & NM & $\mathrm{N}$ & 15 & 2 & $88.2 \%$ & 2 & 0 & $100 \%$ \\
\hline Las Cruces & NM & U & 12 & 0 & $100 \%$ & 1 & 0 & $100 \%$ \\
\hline
\end{tabular}




\begin{tabular}{|c|c|c|c|c|c|c|c|c|}
\hline \multirow[t]{2}{*}{ Table 3. cont } & \multirow[b]{2}{*}{ Road Type* } & \multirow[b]{2}{*}{ City Limits** } & \multicolumn{3}{|c|}{ Passenger Day } & \multicolumn{3}{|c|}{ Passenger Night } \\
\hline & & & Yes & No & Rate & Yes & No & Rate \\
\hline Albuquerque & NM & $\mathrm{U}$ & 11 & 1 & $91.7 \%$ & 2 & 2 & $50.0 \%$ \\
\hline Albuquerque & NM & $\mathrm{U}$ & 19 & 6 & $76.0 \%$ & 16 & 4 & $80.0 \%$ \\
\hline Albuquerque & NM & $U$ & 34 & 2 & $94.4 \%$ & 33 & 11 & $75.0 \%$ \\
\hline Albuquerque & NM & $\mathrm{U}$ & 59 & 3 & $95.2 \%$ & 17 & 3 & $85.0 \%$ \\
\hline Albuquerque & NM & $\mathrm{U}$ & 18 & 3 & $85.7 \%$ & 48 & 5 & $90.6 \%$ \\
\hline Alamagordo & US & $\mathrm{N}$ & 24 & 3 & $88.9 \%$ & 21 & 4 & $84.0 \%$ \\
\hline Alamagordo - White Sands & US & $\mathrm{N}$ & 22 & 1 & $95.7 \%$ & 13 & 7 & $65.0 \%$ \\
\hline Alamogordo & US & $U$ & 15 & 3 & $83.3 \%$ & 8 & 1 & $88.9 \%$ \\
\hline Santa Fe to the North & US & $\mathrm{N}$ & 6 & 1 & $85.7 \%$ & 1 & 1 & $50.0 \%$ \\
\hline Santa Fe to the North & US & $\mathrm{N}$ & 14 & 1 & $93.3 \%$ & 1 & 0 & $100 \%$ \\
\hline Carlsbad & US & $U$ & 46 & 4 & $92.0 \%$ & 5 & 1 & $83.3 \%$ \\
\hline Carlsbad & US & $U$ & 26 & 1 & $96.3 \%$ & 7 & 1 & $87.5 \%$ \\
\hline Carlsbad & US & $U$ & 22 & 3 & $88.0 \%$ & 6 & 1 & $85.7 \%$ \\
\hline Clovis & US & $U$ & 30 & 3 & $90.9 \%$ & 10 & 5 & $66.7 \%$ \\
\hline Clovis & US & $\mathrm{N}$ & 29 & 3 & $90.6 \%$ & 32 & 5 & $86.5 \%$ \\
\hline Clovis & US & $\mathrm{N}$ & 25 & 2 & $92.6 \%$ & 4 & 0 & $100 \%$ \\
\hline Clovis & US & $\mathrm{N}$ & 8 & 1 & $88.9 \%$ & 5 & 4 & $55.6 \%$ \\
\hline Las Cruces & US & $\mathrm{N}$ & 29 & 1 & $96.7 \%$ & 9 & 1 & $90.0 \%$ \\
\hline Las Cruces & US & $\mathrm{N}$ & 33 & 0 & $100 \%$ & 7 & 1 & $87.5 \%$ \\
\hline Las Cruces - El Paso & US & $\mathrm{N}$ & 18 & 3 & $85.7 \%$ & 8 & 3 & $72.7 \%$ \\
\hline Espinoza & US & $\mathrm{N}$ & 31 & 10 & $75.6 \%$ & 40 & 18 & $69.0 \%$ \\
\hline Farmington - Bloomfield & US & $\mathrm{N}$ & 5 & 0 & $100 \%$ & 0 & 0 & $\mathrm{n} / \mathrm{a}$ \\
\hline Farmington - Shiprock & US & $\mathrm{N}$ & 7 & 8 & $46.7 \%$ & 33 & 16 & $67.3 \%$ \\
\hline Hobbs & US & $U$ & 35 & 9 & $79.5 \%$ & 16 & 10 & $61.5 \%$ \\
\hline Hobbs & US & $\mathrm{N}$ & 29 & 5 & $85.3 \%$ & 1 & 4 & $20.0 \%$ \\
\hline Lovington & US & $\mathrm{N}$ & 3 & 4 & $42.9 \%$ & 1 & 2 & $33.3 \%$ \\
\hline Roswell & US & $U$ & 42 & 9 & $82.4 \%$ & 9 & 4 & $69.2 \%$ \\
\hline Roswell & US & $\mathrm{N}$ & 16 & 1 & $94.1 \%$ & 0 & 0 & $\mathrm{n} / \mathrm{a}$ \\
\hline Roswell & US & $\mathrm{N}$ & 11 & 3 & $78.6 \%$ & 0 & 0 & $\mathrm{n} / \mathrm{a}$ \\
\hline Roswell & US & $\mathrm{N}$ & 28 & 1 & $96.6 \%$ & 0 & 1 & $0.0 \%$ \\
\hline Roswell to the East & US & $\mathrm{N}$ & 5 & 3 & $62.5 \%$ & 3 & 0 & $100 \%$ \\
\hline Roswell to the South & US & $\mathrm{N}$ & 13 & 1 & $92.9 \%$ & 4 & 0 & $100 \%$ \\
\hline Taos to the West & US & $\mathrm{N}$ & 15 & 7 & $68.2 \%$ & 3 & 0 & $100 \%$ \\
\hline Albuquerque & z & $\mathrm{N}$ & 21 & 2 & $91.3 \%$ & 12 & 3 & $80.0 \%$ \\
\hline Albuquerque & z & $\mathrm{N}$ & 47 & 2 & $95.9 \%$ & 14 & 0 & $100 \%$ \\
\hline Santa Fe & z & $U$ & 9 & 0 & $100 \%$ & 1 & 0 & $100 \%$ \\
\hline Santa Fe & $z$ & $U$ & 27 & 2 & $93.1 \%$ & 0 & 0 & $\mathrm{n} / \mathrm{a}$ \\
\hline Santa Fe & $z$ & U & 4 & 0 & $100 \%$ & 5 & 0 & $100 \%$ \\
\hline Santa Fe & z & $U$ & 16 & 6 & $72.7 \%$ & 28 & 2 & $93.3 \%$ \\
\hline Carlsbad & $z$ & $U$ & 21 & 1 & $95.5 \%$ & 4 & 2 & $66.7 \%$ \\
\hline Clovis to the North & $z$ & $\mathrm{~N}$ & 2 & 0 & $100 \%$ & 0 & 0 & $\mathrm{n} / \mathrm{a}$ \\
\hline Las Cruces & $z$ & $\mathrm{~N}$ & 30 & 10 & $75.0 \%$ & 1 & 0 & $100 \%$ \\
\hline Las Cruces - El Paso & z & $\mathrm{N}$ & 42 & 1 & $97.7 \%$ & 2 & 0 & $100 \%$ \\
\hline
\end{tabular}




\begin{tabular}{|c|c|c|c|c|c|c|c|c|}
\hline Table 3. cont & \multirow[b]{2}{*}{ Road Type* } & \multirow[b]{2}{*}{ City Limits** } & \multicolumn{3}{|c|}{ Passenger Day } & \multicolumn{3}{|c|}{ Passenger Night } \\
\hline Location & & & Yes & No & Rate & Yes & No & Rate \\
\hline Eunice & $\mathrm{z}$ & $\mathrm{N}$ & 11 & 4 & $73.3 \%$ & 11 & 8 & $57.9 \%$ \\
\hline Farmington & $z$ & U & 13 & 3 & $81.3 \%$ & 12 & 3 & $80.0 \%$ \\
\hline Farmington & z & U & 11 & 2 & $84.6 \%$ & 4 & 0 & $100 \%$ \\
\hline Gallup & z & U & 27 & 7 & $79.4 \%$ & 0 & 0 & $\mathrm{n} / \mathrm{a}$ \\
\hline Hobbs & z & U & 47 & 12 & $79.7 \%$ & 26 & 3 & $89.7 \%$ \\
\hline Lovington & $z$ & $\mathrm{~N}$ & 8 & 1 & $88.9 \%$ & 19 & 3 & $86.4 \%$ \\
\hline Las Cruces & $z$ & U & 21 & 3 & $87.5 \%$ & 8 & 3 & $72.7 \%$ \\
\hline Las Cruces & $z$ & U & 31 & 3 & $91.2 \%$ & 7 & 0 & $100 \%$ \\
\hline Las Cruces & z & U & 26 & 4 & $86.7 \%$ & 38 & 8 & $82.6 \%$ \\
\hline Las Cruces & $z$ & U & 9 & 1 & $90.0 \%$ & 4 & 2 & $66.7 \%$ \\
\hline Las Cruces & $z$ & U & 31 & 1 & $96.9 \%$ & 9 & 2 & $81.8 \%$ \\
\hline Las Cruces & $z$ & U & 16 & 2 & $88.9 \%$ & 13 & 1 & $92.9 \%$ \\
\hline Las Cruces & $z$ & U & 61 & 4 & $93.8 \%$ & 6 & 0 & $100 \%$ \\
\hline Las Cruces & $z$ & U & 26 & 2 & $92.9 \%$ & 41 & 5 & $89.1 \%$ \\
\hline Albuquerque & $z$ & U & 19 & 1 & $95.0 \%$ & 28 & 2 & $93.3 \%$ \\
\hline Albuquerque & $z$ & U & 43 & 4 & $91.5 \%$ & 40 & 4 & $90.9 \%$ \\
\hline Albuquerque & $z$ & U & 9 & 1 & $90.0 \%$ & 1 & 0 & $100 \%$ \\
\hline Albuquerque & $z$ & U & 21 & 2 & $91.3 \%$ & 39 & 3 & $92.9 \%$ \\
\hline Albuquerque & $z$ & U & 6 & 2 & $75.0 \%$ & 4 & 1 & $80.0 \%$ \\
\hline Albuquerque & $z$ & U & 49 & 5 & $90.7 \%$ & 22 & 6 & $78.6 \%$ \\
\hline Albuquerque & $z$ & U & 18 & 1 & $94.7 \%$ & 5 & 2 & $71.4 \%$ \\
\hline Albuquerque & $z$ & U & 12 & 2 & $85.7 \%$ & 21 & 0 & $100 \%$ \\
\hline Albuquerque & $z$ & U & 4 & 1 & $80.0 \%$ & 13 & 2 & $86.7 \%$ \\
\hline Albuquerque & z & U & 23 & 2 & $92.0 \%$ & 6 & 2 & $75.0 \%$ \\
\hline
\end{tabular}


Table 4. Day and Night Overall (Driver and Passenger) Belt Use in New Mexico, by Site

\begin{tabular}{|c|c|c|c|c|c|c|c|c|}
\hline \multirow[b]{2}{*}{ Location } & \multirow[b]{2}{*}{ Road Type* } & \multirow[b]{2}{*}{ City Limits** } & \multicolumn{3}{|c|}{ ALL DAY } & \multicolumn{3}{|c|}{ ALL NIGHT } \\
\hline & & & Yes & No & Rate & Yes & No & Rate \\
\hline Albuquerque & I & $\mathrm{N}$ & 56 & 1 & $98.2 \%$ & 76 & 1 & $98.7 \%$ \\
\hline Santa Fe to the South & I & $\mathrm{N}$ & 95 & 20 & $82.6 \%$ & 134 & 21 & $86.5 \%$ \\
\hline Santa Fe to the South & I & $\mathrm{N}$ & 114 & 18 & $86.4 \%$ & 85 & 2 & $97.7 \%$ \\
\hline Santa Fe to the South & I & $\mathrm{N}$ & 9 & 0 & $100 \%$ & 11 & 1 & $91.7 \%$ \\
\hline Las Cruces & I & $\mathrm{N}$ & 32 & 2 & $94.1 \%$ & 7 & 2 & $77.8 \%$ \\
\hline Las Cruces - El Paso & 1 & $\mathrm{~N}$ & 44 & 5 & $89.8 \%$ & 53 & 6 & $89.8 \%$ \\
\hline Las Cruces - El Paso & I & $\mathrm{N}$ & 82 & 3 & $96.5 \%$ & 14 & 0 & $100 \%$ \\
\hline Demming & I & $\mathrm{N}$ & 0 & 1 & $0.0 \%$ & 1 & 0 & $100 \%$ \\
\hline Demming & I & $\mathrm{N}$ & 11 & 2 & $84.6 \%$ & 1 & 1 & $50.0 \%$ \\
\hline Espinoza & I & U & 80 & 11 & $87.9 \%$ & 66 & 32 & $67.3 \%$ \\
\hline Gallup & I & U & 68 & 7 & $90.7 \%$ & 4 & 1 & $80.0 \%$ \\
\hline Gallup & I & U & 75 & 8 & $90.4 \%$ & 101 & 35 & $74.3 \%$ \\
\hline Gallup & I & $\mathrm{N}$ & 16 & 0 & $100 \%$ & 18 & 3 & $85.7 \%$ \\
\hline Gallup to the East & I & $\mathrm{N}$ & 24 & 0 & $100 \%$ & 0 & 2 & $0.0 \%$ \\
\hline Las Cruces & I & U & 21 & 0 & $100 \%$ & 5 & 0 & $100 \%$ \\
\hline Las Cruces & I & U & 67 & 2 & $97.1 \%$ & 108 & 9 & $92.3 \%$ \\
\hline Las Cruces & I & U & 123 & 2 & $98.4 \%$ & 48 & 8 & $85.7 \%$ \\
\hline Las Cruces & I & U & 48 & 7 & $87.3 \%$ & 33 & 3 & $91.7 \%$ \\
\hline Albuquerque & I & $U$ & 33 & 9 & $78.6 \%$ & 11 & 2 & $84.6 \%$ \\
\hline Albuquerque & I & U & 83 & 5 & $94.3 \%$ & 9 & 0 & $100 \%$ \\
\hline Albuquerque & I & U & 28 & 3 & $90.3 \%$ & 5 & 0 & $100 \%$ \\
\hline Albuquerque & I & U & 56 & 8 & $87.5 \%$ & 12 & 1 & $92.3 \%$ \\
\hline Albuquerque & 1 & U & 72 & 6 & $92.3 \%$ & 8 & 4 & $66.7 \%$ \\
\hline Albuquerque & NM & $\mathrm{N}$ & 100 & 4 & $96.2 \%$ & 120 & 17 & $87.6 \%$ \\
\hline Albuquerque & NM & $\mathrm{N}$ & 35 & 2 & $94.6 \%$ & 4 & 3 & $57.1 \%$ \\
\hline Albuquerque & NM & $\mathrm{N}$ & 68 & 13 & $84.0 \%$ & 83 & 13 & $86.5 \%$ \\
\hline Santa Fe to the East & NM & $\mathrm{N}$ & 43 & 9 & $82.7 \%$ & 18 & 5 & $78.3 \%$ \\
\hline Carlsbad & NM & $\mathrm{N}$ & 87 & 7 & $92.6 \%$ & 163 & 29 & $84.9 \%$ \\
\hline Clovis & NM & $\mathrm{N}$ & 36 & 10 & $78.3 \%$ & 6 & 0 & $100 \%$ \\
\hline Las Cruces - El Paso & NM & $\mathrm{N}$ & 77 & 1 & $98.7 \%$ & 216 & 6 & $97.3 \%$ \\
\hline El Rancho - Santa Fe & NM & $\mathrm{N}$ & 58 & 7 & $89.2 \%$ & 18 & 2 & $90.0 \%$ \\
\hline Espanola -Santa Fe & NM & U & 91 & 35 & $72.2 \%$ & 11 & 17 & $39.3 \%$ \\
\hline Farmington & NM & $\mathrm{N}$ & 43 & 4 & $91.5 \%$ & 25 & 3 & $89.3 \%$ \\
\hline Farmington & NM & $\mathrm{N}$ & 32 & 8 & $80.0 \%$ & 31 & 9 & $77.5 \%$ \\
\hline Gallup & NM & $\mathrm{N}$ & 66 & 15 & $81.5 \%$ & 18 & 0 & $100 \%$ \\
\hline Hobbs & NM & U & 126 & 37 & $77.3 \%$ & 138 & 45 & $75.4 \%$ \\
\hline Hobbs & NM & $\mathrm{N}$ & 87 & 15 & $85.3 \%$ & 36 & 17 & $67.9 \%$ \\
\hline Lovington & NM & $\mathrm{N}$ & 36 & 20 & $64.3 \%$ & 19 & 13 & $59.4 \%$ \\
\hline Lovington & NM & $\mathrm{N}$ & 87 & 28 & $75.7 \%$ & 26 & 12 & $68.4 \%$ \\
\hline Tijeras & NM & $\mathrm{N}$ & 60 & 8 & $88.2 \%$ & 15 & 3 & $83.3 \%$ \\
\hline Las Cruces & NM & U & 37 & 4 & $90.2 \%$ & 5 & 0 & $100 \%$ \\
\hline
\end{tabular}




\begin{tabular}{|c|c|c|c|c|c|c|c|c|}
\hline \multirow[t]{2}{*}{ Table 4. cont } & \multirow[b]{2}{*}{ Road Type* } & \multirow[b]{2}{*}{ City Limits** } & \multicolumn{3}{|c|}{ ALL DAY } & \multicolumn{3}{|c|}{ ALL NIGHT } \\
\hline & & & Yes & No & Rate & Yes & No & Rate \\
\hline Albuquerque & NM & U & 40 & 3 & $93.0 \%$ & 9 & 5 & $64.3 \%$ \\
\hline Albuquerque & NM & $U$ & 90 & 18 & $83.3 \%$ & 61 & 11 & $84.7 \%$ \\
\hline Albuquerque & NM & $U$ & 127 & 15 & $89.4 \%$ & 101 & 35 & $74.3 \%$ \\
\hline Albuquerque & NM & U & 180 & 7 & $96.3 \%$ & 71 & 11 & $86.6 \%$ \\
\hline Albuquerque & NM & $U$ & 135 & 20 & $87.1 \%$ & 161 & 28 & $85.2 \%$ \\
\hline Alamagordo & US & $\mathrm{N}$ & 93 & 13 & $87.7 \%$ & 61 & 14 & $81.3 \%$ \\
\hline Alamagordo - White Sands & US & $\mathrm{N}$ & 88 & 10 & $89.8 \%$ & 66 & 18 & $78.6 \%$ \\
\hline Alamogordo & US & $U$ & 57 & 16 & $78.1 \%$ & 19 & 2 & $90.5 \%$ \\
\hline Santa Fe to the North & US & $\mathrm{N}$ & 32 & 5 & $86.5 \%$ & 7 & 2 & $77.8 \%$ \\
\hline Santa Fe to the North & US & $\mathrm{N}$ & 32 & 2 & $94.1 \%$ & 6 & 0 & $100 \%$ \\
\hline Carlsbad & US & $U$ & 183 & 34 & $84.3 \%$ & 19 & 8 & $70.4 \%$ \\
\hline Carlsbad & US & $U$ & 110 & 20 & $84.6 \%$ & 30 & 5 & $85.7 \%$ \\
\hline Carlsbad & US & $U$ & 111 & 19 & $85.4 \%$ & 19 & 10 & $65.5 \%$ \\
\hline Clovis & US & U & 116 & 17 & $87.2 \%$ & 48 & 12 & $80.0 \%$ \\
\hline Clovis & US & $\mathrm{N}$ & 118 & 15 & $88.7 \%$ & 120 & 25 & $82.8 \%$ \\
\hline Clovis & US & $\mathrm{N}$ & 106 & 10 & $91.4 \%$ & 26 & 3 & $89.7 \%$ \\
\hline Clovis & US & $\mathrm{N}$ & 41 & 7 & $85.4 \%$ & 23 & 7 & $76.7 \%$ \\
\hline Las Cruces & US & $\mathrm{N}$ & 128 & 9 & $93.4 \%$ & 57 & 5 & $91.9 \%$ \\
\hline Las Cruces & US & $\mathrm{N}$ & 154 & 10 & $93.9 \%$ & 30 & 4 & $88.2 \%$ \\
\hline Las Cruces - El Paso & US & $\mathrm{N}$ & 56 & 8 & $87.5 \%$ & 41 & 7 & $85.4 \%$ \\
\hline Espinoza & US & $\mathrm{N}$ & 105 & 38 & $73.4 \%$ & 141 & 44 & $76.2 \%$ \\
\hline Farmington - Bloomfield & US & $\mathrm{N}$ & 33 & 9 & $78.6 \%$ & 0 & 0 & $\mathrm{n} / \mathrm{a}$ \\
\hline Farmington - Shiprock & US & $\mathrm{N}$ & 34 & 23 & $59.6 \%$ & 94 & 50 & $65.3 \%$ \\
\hline Hobbs & US & $U$ & 103 & 35 & $74.6 \%$ & 58 & 19 & $75.3 \%$ \\
\hline Hobbs & US & $\mathrm{N}$ & 82 & 16 & $83.7 \%$ & 11 & 15 & $42.3 \%$ \\
\hline Lovington & US & $\mathrm{N}$ & 18 & 12 & $60.0 \%$ & 3 & 10 & $23.1 \%$ \\
\hline Roswell & US & $U$ & 163 & 28 & $85.3 \%$ & 29 & 13 & $69.0 \%$ \\
\hline Roswell & US & $\mathrm{N}$ & 53 & 5 & $91.4 \%$ & 0 & 2 & $0.0 \%$ \\
\hline Roswell & US & $\mathrm{N}$ & 48 & 5 & $90.6 \%$ & 1 & 2 & $33.3 \%$ \\
\hline Roswell & US & $\mathrm{N}$ & 95 & 14 & $87.2 \%$ & 3 & 5 & $37.5 \%$ \\
\hline Roswell to the East & US & $\mathrm{N}$ & 14 & 5 & $73.7 \%$ & 10 & 0 & $100 \%$ \\
\hline Roswell to the South & US & $\mathrm{N}$ & 47 & 8 & $85.5 \%$ & 12 & 1 & $92.3 \%$ \\
\hline Taos to the West & US & $\mathrm{N}$ & 59 & 18 & $76.6 \%$ & 8 & 0 & $100 \%$ \\
\hline Albuquerque & z & $\mathrm{N}$ & 72 & 10 & $87.8 \%$ & 50 & 10 & $83.3 \%$ \\
\hline Albuquerque & z & $\mathrm{N}$ & 164 & 14 & $92.1 \%$ & 77 & 8 & $90.6 \%$ \\
\hline Santa Fe & z & $U$ & 90 & 13 & $87.4 \%$ & 7 & 1 & $87.5 \%$ \\
\hline Santa Fe & z & U & 127 & 21 & $85.8 \%$ & 9 & 0 & $100 \%$ \\
\hline Santa Fe & z & U & 24 & 3 & $88.9 \%$ & 26 & 1 & $96.3 \%$ \\
\hline Santa Fe & z & $U$ & 72 & 14 & $83.7 \%$ & 109 & 11 & $90.8 \%$ \\
\hline Carlsbad & $z$ & $U$ & 78 & 10 & $88.6 \%$ & 57 & 23 & $71.3 \%$ \\
\hline Clovis to the North & $z$ & $\mathrm{~N}$ & 24 & 4 & $85.7 \%$ & 0 & 0 & $\mathrm{n} / \mathrm{a}$ \\
\hline Las Cruces & $z$ & $\mathrm{~N}$ & 145 & 25 & $85.3 \%$ & 13 & 0 & $100 \%$ \\
\hline Las Cruces - El Paso & z & $\mathrm{N}$ & 180 & 2 & $98.9 \%$ & 9 & 0 & $100 \%$ \\
\hline
\end{tabular}




\begin{tabular}{|c|c|c|c|c|c|c|c|c|}
\hline \multirow[t]{2}{*}{ Table 4. cont } & \multirow[b]{2}{*}{ Road Type* } & \multirow[b]{2}{*}{ City Limits** } & \multicolumn{3}{|c|}{ ALL DAY } & \multicolumn{3}{|c|}{ ALL NIGHT } \\
\hline & & & Yes & No & Rate & Yes & No & Rate \\
\hline Eunice & z & $\mathrm{N}$ & 35 & 10 & $77.8 \%$ & 33 & 22 & $60.0 \%$ \\
\hline Farmington & $z$ & U & 80 & 9 & $89.9 \%$ & 38 & 9 & $80.9 \%$ \\
\hline Farmington & z & U & 55 & 17 & $76.4 \%$ & 9 & 3 & $75.0 \%$ \\
\hline Gallup & z & U & 108 & 25 & $81.2 \%$ & 0 & 0 & $\mathrm{n} / \mathrm{a}$ \\
\hline Hobbs & z & U & 149 & 36 & $80.5 \%$ & 66 & 19 & $77.6 \%$ \\
\hline Lovington & $z$ & $\mathrm{~N}$ & 28 & 10 & $73.7 \%$ & 51 & 16 & $76.1 \%$ \\
\hline Las Cruces & $z$ & U & 87 & 10 & $89.7 \%$ & 32 & 11 & $74.4 \%$ \\
\hline Las Cruces & $z$ & U & 114 & 16 & $87.7 \%$ & 29 & 5 & $85.3 \%$ \\
\hline Las Cruces & z & U & 112 & 12 & $90.3 \%$ & 125 & 23 & $84.5 \%$ \\
\hline Las Cruces & $z$ & U & 58 & 3 & $95.1 \%$ & 14 & 5 & $73.7 \%$ \\
\hline Las Cruces & $z$ & U & 98 & 8 & $92.5 \%$ & 35 & 7 & $83.3 \%$ \\
\hline Las Cruces & $z$ & U & 94 & 7 & $93.1 \%$ & 45 & 3 & $93.8 \%$ \\
\hline Las Cruces & $z$ & U & 194 & 16 & $92.4 \%$ & 29 & 2 & $93.5 \%$ \\
\hline Las Cruces & z & U & 145 & 6 & $96.0 \%$ & 134 & 12 & $91.8 \%$ \\
\hline Albuquerque & $z$ & U & 70 & 2 & $97.2 \%$ & 87 & 7 & $92.6 \%$ \\
\hline Albuquerque & $z$ & U & 145 & 13 & $91.8 \%$ & 160 & 22 & $87.9 \%$ \\
\hline Albuquerque & $z$ & U & 54 & 5 & $91.5 \%$ & 5 & 2 & $71.4 \%$ \\
\hline Albuquerque & $z$ & U & 84 & 8 & $91.3 \%$ & 140 & 15 & $90.3 \%$ \\
\hline Albuquerque & $z$ & U & 75 & 6 & $92.6 \%$ & 22 & 2 & $91.7 \%$ \\
\hline Albuquerque & $z$ & U & 192 & 16 & $92.3 \%$ & 100 & 16 & $86.2 \%$ \\
\hline Albuquerque & $z$ & U & 85 & 7 & $92.4 \%$ & 19 & 5 & $79.2 \%$ \\
\hline Albuquerque & $z$ & U & 94 & 8 & $92.2 \%$ & 93 & 4 & $95.9 \%$ \\
\hline Albuquerque & $z$ & U & 39 & 4 & $90.7 \%$ & 46 & 9 & $83.6 \%$ \\
\hline Albuquerque & z & U & 78 & 10 & $88.6 \%$ & 34 & 7 & $82.9 \%$ \\
\hline
\end{tabular}



DOT HS 810705

January 2007
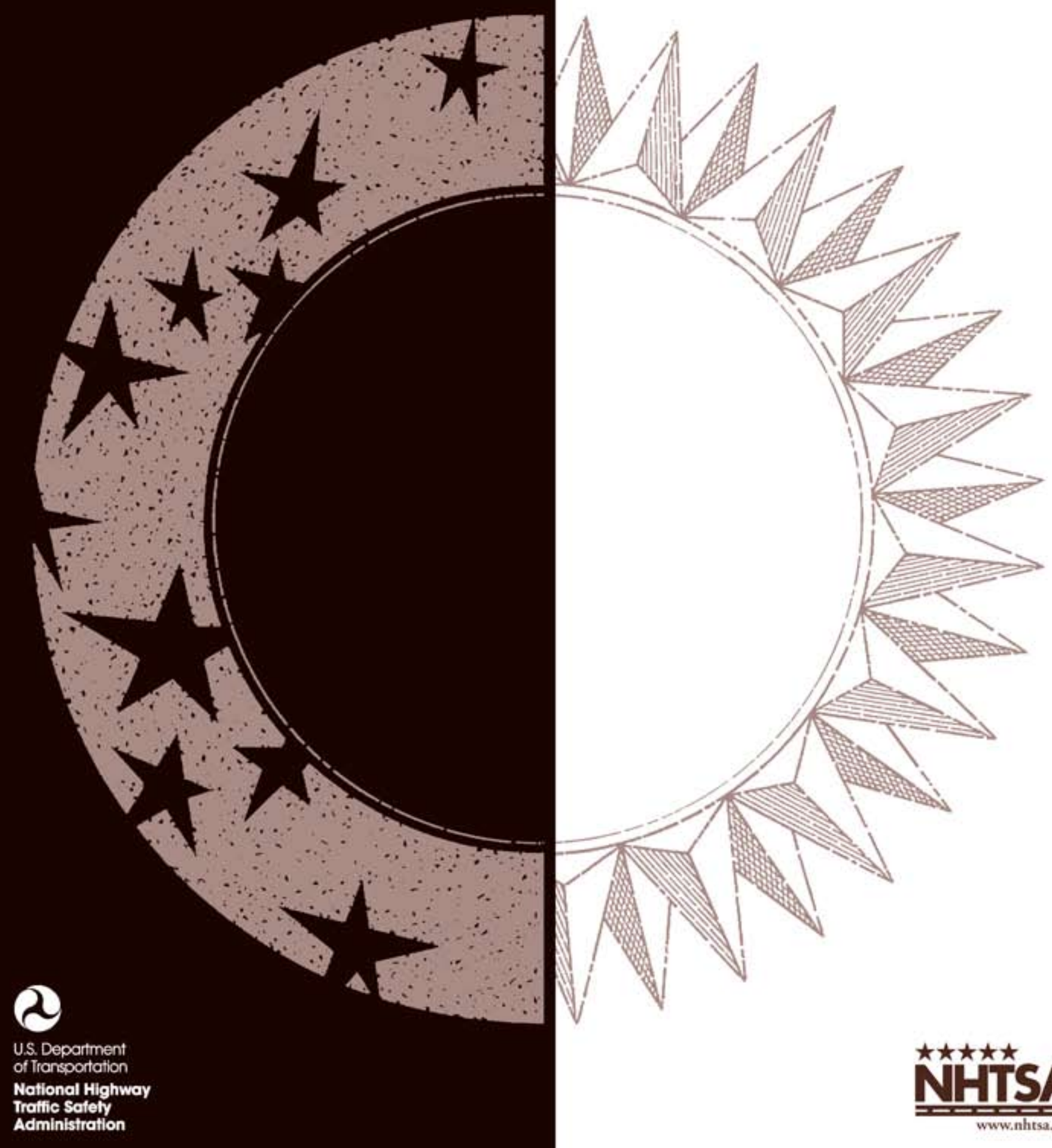

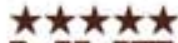
NHTSA www.nhtsa.gov 